\title{
Risk of HIV Transmission through Sexual Activities: A Survey among HIV-Positive Gay Men in Jember, Indonesia
}

\section{Dicky Endrian Kurniawan1, Lantin Sulistyorini ${ }^{1}$, Kholid Rosyidi Muhammad Nur ${ }^{1 *}$, M. Nur Khamid², Alfid Tri Afandi ${ }^{1}$, Retno Purwandari ${ }^{1}$, Anisah Ardiana ${ }^{1}$}

${ }^{1}$ Faculty of Nursing, Universitas Jember, Indonesia; kholidrosyidi.psik@unei.ac.id (Corresponding Author) 2LASKAR Foundation, Jember, Indonesia

\begin{tabular}{|c|c|}
\hline Article Info: & ABSTRACT \\
\hline Submitted: & Prevention of HIV transmission can be done through safe sexual activities. It can occur \\
\hline 28-05-2021 & if HIV-positive gay men or men who sex men (MSM) did not have sex with men or use \\
\hline Revised: & a condom. This study aimed to identify the preventive behavior of HIV transmission \\
\hline 19-06-2021 & through sexual activities among HIV-positive gay men. This study used a quantitative \\
\hline Accepted: & design with a descriptive exploratory approach. One hundred and one HIV-positive gay \\
\hline 19-06-2021 & $\begin{array}{l}\text { men were collected by using purposive sampling following this study. Data were } \\
\text { collected by a questionnaire of preventive behavior of HIV transmission through sexual }\end{array}$ \\
\hline DOI: & behavior and analyzed with an exploratory, descriptive approach. Almost all MSM still \\
\hline https://doi.org/10.53713/nhs.v1i1.14 & have sex (96\%) after they have been diagnosed HIV-positive, and most do not always \\
\hline & $\begin{array}{l}\text { use a condom }(74.3 \%) \text {. Sexual prevention behavior in MSM is still low and it can } \\
\text { increase new HIV cases. Efforts are needed against HIV transmission among the gay }\end{array}$ \\
\hline (c) & commitment when they have the same sexual activities. \\
\hline
\end{tabular}

This work is licensed under CC BY-SA License.
Keyword: preventive behavior, HIV transmission, sexual activities, gay men

\section{INTRODUCTION}

The number of HIV / AIDS case reports in Indonesia continues to increase every year (Ministry of Health, 2018). Although the incidence in Indonesia is quite large, the problem is still believed to be an iceberg phenomenon, where the number of reports does not reflect the real problem (Hardisman et al., 2018). The second-rank of the percentage of HIV infections is MSM groups (Ministry of Health, 2018). People with HIV I AIDS (PLWHA) newly found in the MSM group tend to increase. There was about a $16 \%$ increase from 2010 to 2018. This shows the problem of a significant increase in HIV / AIDS transmission among MSM.

The high increase in the number of new HIV / AIDS infections in Indonesia can be caused by risky behavior of transmitting HIV to others. In addition, the previous study suggests some MSM might be better off discussing HIV prevention with their male sexual partners than using condoms. Even in another study, PLWHA only tries without being based on actions that guarantee MSM's efforts to use condoms as a precaution for HIV transmission, because there is a large proportion of MSM who are found to still have sex by not using condoms (Fauziah et al., 2018). Negotiations on condom use, condom unavailability, discomfort, and uncertainty about the effectiveness of condoms may lead behavior to prevent HIV transmission. This phenomenon can also increase, rather than reduce HIV transmission (O'Byrne et al., 2014), especially among the MSM group.

Prevention of HIV transmission can be done through the efforts of "ABCDE" (Abstinence, Be Faithful, Condom, No Drug, and Education) (Ministry of Health, 2016). This study aims to identify the preventive behavior of HIV transmission through sexual activities among MSM, especially abstinence, faithful, and condom use.

\section{METHOD}

A descriptive explorative method were used in this study. One hundred and one HIV-positive MSM who joined LASKAR Foundation (a non-governmental organization) were collected by using purposive sampling following this study in October 2019. 
Data were collected by preventive behavior of HIV transmission through sexual behavior questionnaire (modified from Konam (2015) and Kemenkes (2016)). Questionnaire were validated by using Content Validity Index (CVI) with score of mean $\mathrm{i}-\mathrm{CV} \mid=1.00$. Data were analyzed with exploratory descriptive approach.

Ethical approval was declared by the Health Research Ethics Committee of the Faculty of Nursing, Universitas Jember with registration number 4878/UN25.1.14/SP/2019.

\section{RESULT}

\section{Respondents' Characteristics}

According to Table 1, average of respondents' age in this study was 28 years old (the youngest is 18 and the oldest is 45). Almost all HIV-positive MSM still unmarriage (89.1). More than half of MSM lives in their/familys' house $(64.4 \%)$, following by in the kost (19.8\%) and rented house (15.8\%). Almost half of MSM lives alone (45.5\%). The role of respondents in sexual activity is almost equally distributed as top, bottom, and versatile. Almost of them didn't know about HIV status of their male sexual partner (77.2\%). According to table 2. almost all respondents still have sex with men (96\%) with a consistent intensity of using condoms only $25.7 \%$; in fact, nearly all respondents still have sex through anal $(98 \%)$.

Table 1. Respondents' Characteristics $(n=101)$

\begin{tabular}{lc}
\hline \multicolumn{1}{c}{ Variable } & $\mathrm{n}(\%)$ \\
\hline Age (years old) & \\
Mean (min-max) $=28.02(18-45)$ & \\
\hline Marrital Status & $5(5.0)$ \\
Marriage & $90(89.1)$ \\
Unmarriage & $6(5.9)$ \\
Divorced & \\
\hline Living place & $20(19.8)$ \\
In the kost & $16(15.8)$ \\
Rented house & $65(64.4)$ \\
Private/Familys' house & \\
\hline Living partner & $46(45.5)$ \\
Alone & $52(51.5)$ \\
Family & $3(3.0)$ \\
Male sexual partner & \\
\hline Role in sexual activities with men & $32(31.7)$ \\
Top & $31(30.7)$ \\
Bottom & $38(37.6)$ \\
Versatile & \\
\hline HIV positive of men sexual partner & $9(8.9)$ \\
Yes & $14(13.9)$ \\
No & $78(77.2)$ \\
Don't know & \\
&
\end{tabular}


Table2. Preventive Behavior of HIV Transmission through Sexual Activities among MSM ( $n=101)$

\begin{tabular}{lc}
\hline \multicolumn{1}{c}{ Variable } & $\mathrm{n}(\%)$ \\
\hline Still having sex between men & \\
Yes & $97(96.0)$ \\
No & $4(4.0)$ \\
\hline Many sexual partners nowadays & \\
One & $57(56.4)$ \\
Two & $17(16.8)$ \\
Three & $3(3.0)$ \\
More than three & $13(12.9)$ \\
None & $11(10.9)$ \\
\hline Many sexual partners last 6 months & \\
One & $43(42.6)$ \\
Two & $28(27.7)$ \\
Three & $6(5.9)$ \\
More than three & $14(13.9)$ \\
None & $10(9.9)$ \\
\hline Faithful with a male partner & \\
Yes & $44(43.6)$ \\
No & $31(30.7)$ \\
Not sure & $26(25.7)$ \\
\hline Intensity of using condoms during sex with men & \\
Never & $1(1.0)$ \\
Rarely & $22(21.8)$ \\
Often & $52(51.5)$ \\
Always & $26(25.7)$ \\
\hline Refuse to have unprotected sex & \\
Never & $7(6.9)$ \\
Rarely & $29(28.7)$ \\
Often & $22(21.8)$ \\
Always & $43(42.6)$ \\
\hline Reasons for not refusing to have sex without a condom & \\
(answer may be more than one) & \\
Afraid to be asked why & $2(2.0)$ \\
Uncomfortable & $16(15.8)$ \\
Feels sick or hot & $58(57.4)$ \\
Haven't anal sex & $25(24.8)$ \\
$\quad$ Male partners are also HIV positive & \\
Others & $40(39.6)$ \\
\hline Reasons for refusing to have sex without a condom & $41(40.6)$ \\
(answer may be more than one) & $20(19.8)$ \\
Don't want to have sexual transmitted diseases other than HIV & $6(5.9)$ \\
So other people are not infected HIV & $4(4.0)$ \\
\hline Having oral sex with men & $13(12.9)$ \\
$\quad$ Never & \\
Rarely & \\
Often & $66(65.3)$ \\
Always & $44(43.6)$ \\
\hline Having anal sex with men & $2(2.0)$ \\
Never & $20(19.8)$ \\
Often & $72(71.3)$ \\
Always & $7(6.9)$ \\
\hline
\end{tabular}




\section{DISCUSSION}

In the sexual behavior of PLWHA-MSM, almost all of them still have sex with other men, although some don't have sex with men anymore. It was higher than previous studies showed that about $60 \%$ of MSM report unprotected anal sex with HIV-negative or unknown HIV status (Cloete \& Simbayi, 2008). When having sex with men, most do not always use condoms and do not always refuse to have sex without a condom. The less-used condoms, the higher the risk of HIV infection (Torres et al., 2017). It has become one of the factors increasing the number of HIV cases in MSM.

The reason they feel sick or hot, uncomfortable, and afraid of being asked the reason or accused of being HIV positive. Their disclosure may influence it; a previous study also mentioned that almost all positive MSM did not tell their status to their sexual partners (Kurniawan \& Sulistyorini, 2019). Respondents who always refused to use condoms mostly reasoned that others would not be infected and not be infected with other sexual diseases.

That phenomenon was a particular concern because most respondents still have sexual intercourse through oral and anal. The risk that can occur is the increasing number of MSM HIV-positive or other sexually transmitted disease problems. Many studies showed that having anal sex has a more significant risk of HIV transmission. The majority of MSM do not always use condoms when having sex. A previous study mentioned that unprotective anal sex has a high risk of HIV transmission. Low use of condoms in MSM has a direct relationship with the occurrence of HIV transmission. In addition, it means their sexual activities has high risk for transmission of HIV among MSM.

\section{CONCLUSION}

Almost all MSM who are HIV positive still have sex with men; almost all of them have anal sex, and not all MSM always use condoms. Efforts are needed to handle HIV transmission in gay men population by adequate information on MSM to increase awareness of condom use, including the program for easy access to condom for MSM.

\section{ACKNOWLEDGEMENT}

Lembaga Penelitian \& Pengabdian kepada Masyarakat (LP2M) Universitas Jember supported this study in the grant program of "Penelitian Dosen Pemula" in 2019. The researchers, thanks to the Yayasan LASKAR and all parties involved in this research.

\section{REFERENCES}

Aliyah, A.N.G, Rifai, A., \& Afandi, A.T. (2019). Kualitas Tidur Orang Dengan Hiv/Aids (Odha) Di Area Pedesaan Kabupaten Jember Indonesia. Vol 1 No 1 (2019): Prosiding RMIK Politeknik Negeri Jember

Centers for Disease Control and Prevention (CDC). (2019). HIV among gay and bisexual men. US: Department of Health and Human Services

Chaudoir, S.R., J.D. Fisher, \& J.M. Simoni. (2011). Understanding HIV disclosure: A review and application of the disclosure processes model. Social Science \& Medicine. 72(10)

Cloete, A., L.C. Simbayi, \& S.C. Kalichman. (2008). Disclosure decisions and HIV positive men who have sex with men (MSM) in Cape Town, South Africa. Paper presented at the AIDS Conference, Mexico City, 7 August.

Devito, J.A. (2013). The interpersonal communication book (13th ed.).New York: Pearson

Fauziyah, Z. Shaluhiyah, \& P. M P. (2018). Respon remaja lelaki suka lelaki (LSL) dengan status HIV positif terhadap pencegahan penularan HIV kepada pasangan. Jurnal Promosi Kesehatan Indonesia. 13(1)

Fraenkel. J. R, \& N. E. Wallen. (2006). How to design and evaluate research in education(Ed. 6). New York, US: McGraw-Hill

Gunawan, A.H. (2014). Hubungan keterbukaan ODHA pada pasangan dengan tindakan pencegahan penularan HIVIAIDS (melalui safer-sex \& PMTCT) pada keluarga oleh ODHA. Skripsi. Universitas Muhammadiyah Malang

Hardisman, Firdawati, \& I.N. Sulrieni. (2018). Model determinan perilaku "lelaki seks lelaki" di Kota Pa\&g, Sumatera Barat. Jurnal Kesehatan Andalas. 7(3)

Hua, J., C.B. Emrick, C.E. Golin, K. Liu, J. Pan, M. Wang, X. Wan, W. Chen, \& N. Jiang. (2014). HIV and stigma in Liuzhou, China. AIDS Behav. 18(Suppl 2)

Jayakumaran, J.S, E. Aaron, E.J. Gracely, E. Schriver, \& Z. Szep. (2016). Knowledge, attitudes, and acceptability of pre-exposure prophylaxis among individuals living with HIV in an urban HIV clinic. PLOS ONE. 11(2)

Kemenkes RI. (2016). Program pengendalian HIV AIDS \& PMS di fasilitas kesehatan tingkat pertama.Direktorat Jenderal Pencegahan \& Pengendalian Penyakit 
Kemenkes RI. (2018). Situasi umum HIV/AIDS \& tes HIV. InfoDATIN

Konam, K.A.B. (2015). Barriers to Disclosure of HIV Positive Status to Sexual Partner(s) in The Central Region, Ghana. Thesis. University of Ghana, Legon.

Kurniawan, D.E. (2017). Penyelesaian masalah etik \& legal dalam penelitian keperawatan. Jurnal IImiah Kesehatan Rustida. 3(2).

Marthin, D.M.A. (2011). Studi deskriptif: Pengungkapan diri pada ODHA (Orang Dengan HIVIAIDS) yang berada di wilayah Daerah Istimewa Yogyakarta (DIY). Skripsi. Universitas Sanata Dharma

O'Byrne, P, J. C. Phillips, C. Kitson, \& A. Bryan. (2014). HIV status and sexual behaviour among gay men in Ottawa: considerations for public health. BMJ Open. 4:e005065.

Rouleau, G., J. Côté, \& C. Cara. (2012). Disclosure experience in a convenience sample of quebec-born women living with HIV: A phenomenological study. BMC Women's Health. 12(37)

Simbayi, L.C., S.C. Kalichman, A. Strebel, A. Cloete, N. Henda, \& A. Mqekoto. (2006). Disclosure of HIV status to sex partners and sexual risk behaviours among HIV-positive men and women, Cape Town, South Africa. Sex Transm Infect. 83

Zoebazary, M. I. (2017). Orang Pendalungan: Penganyam kebudayaan di tapal kuda. Jember: Paguyuban Pandhalungan Jember 